\title{
Tatalaksana Vasospasme Cerebral Pasca Perdarahan Subarahnoid
}

\author{
Monika Widiastuti ${ }^{*}$ Iwan Abdul Rachman ${ }^{* *}$, Zafrullah Khany Jasa ${ }^{* * *}$, Rose Mafiana $\left.{ }^{* * * *}\right)$ \\ ${ }^{*}$ )Departemen Anestesiologi Fakultas Kedokteran Universitas Pelita Harapan-Siloam Hospitals Lippo Village, \\ Tangerang, ${ }^{* *}$ Departemen Anestesiologi dan Terapi Intensif Fakultas Kedokteran Universitas Padjadjaran, Rumah \\ Sakit Dr. Hasan Sadikin Bandung, ${ }^{* * *}$ Departemen Anestesiologi dan Terapi IntensifFakultas Kedokteran Universitas \\ Syiah Kuala, Rumah Sakit Umum Daerah Dr. Zainoel Abidin Banda Aceh, ${ }^{* * * *}$ Departemen Anestesiologi dan \\ Terapi Intensif Fakultas Kedokteran Universitas Sriwijaya, Rumah Sakit Umum Pusat Dr. Mohammad Hoesin \\ Palembang
}

\begin{abstract}
Abstrak
Vasospasme cerebral merupakan penyebab morbiditas dan mortalitas utama pada pasien dengan perdarahan subarahonid. Delayed ischemic neurologic deficit yang berhubungan dengan vasospasme serebral menyebabkan kematian pada $50 \%$ pasien yang bertahan pada periode awal setelah aneurisma ruptur yang ditangani. Onset vasospasme serebral yang bervariasi, mulai dari 24 jam pasca perdarahan subarahnoid atau subarahcnoid hemorrhage (SAH) sampai dengan 14 hari, patofisiologi vasospasme serebral yang kompleks dan cara diagnosis yang masih kontroversial, turut berkontribusi terhadap morbiditas dan mortalitas yang tinggi pada pasien dengan SAH. Evaluasi ketat selama perawatan di ICU untuk mendeteksi kejadian vasospasme serebral awal sangat penting, setiap gejala neurologis baru yang muncul harus diperiksa dan ditangani secepatnya. Banyak obat-obatan yang diteliti untuk mengatasi vasospasme serebral namun efektifitasnya masih dipertanyakan. Tatalaksana utama yang dulu diketahui adalah dengan melakukan terapi triple $H$, namun hal ini sudah ditinggalkan. Induced hypertension menjadi satu-satunya bagian dari terapi triple $H$ yang masih digunakan, namun belum banyak dipergunakan secara luas. Oleh karena itu perlu dikaji lebih lanjut bagaimana tatalaksana SAH untuk mencegah luaran yang buruk.
\end{abstract}

Kata kunci: induced hypertension, nimodipine, perdarahan subarahnoid, tehnik endovaskular, vasospasme cerebral

JNI 2022; 11 (1): 49-57

\section{Management of Cerebral Vasospasm after Subarachnoid Hemorrhage}

\begin{abstract}
Cerebral vasospasm is the main etiology of morbidity and mortality in aneurysmal subarachnoid hemorrhage (SAH) patients. Delayed ischemic neurologic deficits associated with vasospasm may account for as high as $50 \%$ of the deaths in patients who survive the initial period after aneurysm rupture and its treatment. The variant onset of cerebral vasospasm, start from 24 hours after SAH up to 14 days after, complex pathophysiology, and the diagnosis of vasospasm has still been met with some controversy, contribute to the high morbidity and mortality in these patients. Vigilance evaluation during ICU care to detect cerebral vasospasm as early as posssible is essential, any new onset of neurological symptoms need to be investigated and treated immediately. Many studies reported some agents for the treatment of cerebral vasospasm, however their roles remain uncertain. Triple H therapy was known as a main treatment for vasospasm, however it is no longer applied nowadays. Induced hypertension become the only part of Triple $\mathrm{H}$ therapy used yet it is not well recognized. Therefor, there is a need for thorough evaluation regarding treatment of SAH to prevent poor outcomes.
\end{abstract}

Key words: induced hypertension, nimodipine, subarachnoid hemorrhage, endovascular technique, cerebral vasospasm

JNI 2022; 11 (1): 49-57

This article is licensed under

Creative Commons Attribution-NonCommercial-ShareAlike 4.0 International License. 


\section{Pendahuluan}

Vasospasme serebral atau cerebral vasospasm (CVS) adalah penyempitan progresif dari arteri serebral yang mengikuti kejadian perdarahan subarahnoid atau subarachnoid hemorrhage (SAH). ${ }^{1}$ Vasospasme cerebral dicetuskan oleh respons neuro-inflamasi dan dapat mengakibatkan iskemia serebral. Vasospasme cerebral adalah komplikasi serius yang dapat terjadi setelah terjadinya perdarahan subarahnoid atau subarahnoid bleeding (SAH), karena dapat menyebabkan delayed cerebral ischemia (DCI) atau delayed ischemic neurologic deficit (DIND atau infark yang menyebabkan mortalitas dan morbiditas yang tinggi. ${ }^{1,2}$ Monitor atau evaluasi terjadinya vasospasme serebral harus dilakukan dengan ketat sejak hari pertama terjadinya $\mathrm{SAH}$. Kejadian vasospasme serebral puncaknya terjadi 7-10 hari pasca ruptur dari aneurisma dan dapat terjadi hingga 21 hari. Mekanisme terjadinya vasospasme serebral masih belum dipahami sepenuhnya, namun mengarah ke terjadinya mekanisme respons inflamasi akibat adanya ekstravasasi darah ke rongga subarahnoid. Risiko terjadinya vasospasme serebral sebanding dengan volume darah $\mathrm{SAH}$. Kemampuan untuk mengenali gejala klinis awal sangat penting untuk dapat mendiagnosis dan menangani vasospasme serebral dengan cepat. ${ }^{2,3}$ Monitor untuk membantu diagnosis vasospasme serebral semakin berkembang, namun tidak semuanya dapat diaplikasikan kepada pasien. Penanganan vasospasme serebral juga masih kontroversial dan kompleks, meliputi terapi cairan, farmakologis dan endovaskular. ${ }^{2,3}$ Terapi triple $\mathrm{H}$ sudah lama ditinggalkan, namun induced hypertension masih digunakan untuk mencegah vasospasme. Pemahaman tentang tatalaksana vasospasme serebral yang mencakup terapi suportif, farmakologis, dan tindakan invasif, penting diketahui untuk menghindari luaran yang buruk.

\section{Definisi}

Definisivasospasme adalah berkurangnya kaliber atau diameter dari pembuluh darah. Pada kejadian SAH, vasospasme memiliki banyak arti. Vasospasme simtomatik adalah munculnya gejala neurologis baru, penurunan kesadaran, atau keduanya, yang diakibatkan oleh iskemia yang berhubungan dengan vasospasme serebral setelah memastikan tidak ada penyebab perburukan lainnya (seperti hidrosefalus, kejang, gangguan metabolik, infeksi, atau sedasi berlebihan). ${ }^{2}$ Vasospasme angiografi didefinisikan sebagai penyempitan arteri yang sedang-berat pada gambaran digital substraction angiography (DSA) yang tidak berhubungan dengan aterosklerosis, spasme karena kateter, hipoplasia pembuluh darah, dimana velositas alirannya (flow velocity) $120 \mathrm{~cm} /$ detik. $^{2}$

\section{Epidemiologi}

Insiden dari SAH akibat aneurisma adalah 2-16 per 100.000 populasi. Sekitar $30 \%$ penyintas dari SAH akan mengalami DIND atau vasospasme serebral simtomatis. Insidens terbanyak terjadi pada dekade kelima kehidupan. Vasospasme serebral dapat terjadi pada waktu yang dapat terprediksi: onset yang terlambat pada hari ke 3-5, puncak vasospasme serebral pada hari ke 5-14, dan resolusi secara bertahap dalam waktu 2-4 minggu. ${ }^{5}$

\section{Faktor Risiko}

Volume bekuan darah pada rongga subarahnoid merupakan faktor risiko terpenting yang dapat memprediksi terjadinya vasospasme serebral setelah SAH. Skala Fisher yang awalnya menilai volume dan distribusi bekuan darah berdasarkan pada hasil computed tomography (CT) scan saat admisi, dimodifikasi menjadi skala Fisher modifikasi seperti tertera pada Tabel 1. Skala modifikasi ini menilai gambaran CT scan $0-4$, tergantung pada ketebalan dan ada atau tidaknya IVH. ${ }^{1,2}$

Faktor risiko lainnya adalah laju yang lambat untuk pembersihan dari bekuan darah, namun hal ini sulit dinilai dalam praktik klinis. Hilangnya kesadaran saar rutpur aneurisma, derajat neurologis yang buruk saat admisi, riwayat merokok, diabetes mellitus atau hiperglikemia, 
Tabel 1. Skala Fisher Modifikasi dan Risiko Vasospasme

\begin{tabular}{ll}
\hline Skala & Gambaran CT Scan \\
\hline 0 & $\begin{array}{l}\text { Tidak ada SAH atau Intraventricular } \\
\text { hemorrhage (IVH), risiko sangat rendah }\end{array}$ \\
1 & $\begin{array}{l}\text { Lapisan tipis SAH yang fokal atau difus, } \\
\text { tanpa IVH, risiko rendah }\end{array}$ \\
2 & $\begin{array}{l}\text { Lapisan tipis SAH yang fokal atau difus, } \\
\text { dengan IVH, risiko sedang }\end{array}$ \\
3 & $\begin{array}{l}\text { Lapisan tebal SAH yang fokal atau difus, } \\
\text { tanpa IVH, risiko tinggi }\end{array}$ \\
4 & $\begin{array}{l}\text { Lapisan tebal SAH yang fokal aau difus, } \\
\text { dengan IVH, risiko sangat tinggi }\end{array}$ \\
\hline
\end{tabular}

hipertensi, perempuan, usia muda, penggunaan kokain dan lokasi aneurisma juga merupakan prediktor. Lokasi aneurisma di arteri cerebral anterior distal memiliki risiko vasospasme serebral yang lebih tinggi. Sebuah studi yang melibatkan 370 pasien dengan SAH menyatakan hipertrofi ventrikel kiri dan hipertensi merupakan prediktor terjadinya vasospasme serebral berat. ${ }^{2,5-7}$

\section{Patofisiologi}

Perdarahan subarahnoid terjadi karena adanya darah yang memasuki rongga subarahnoid. Darah yang terletak dekat dengan otak menyebabkan iritasidanmenyebabkanbanyakkomplikasi. Darah yang berada di rongga subarahnoid, menganggu aliran LCS karena mengganggu pembersihannya di granulasi arahnoid, oleh karena itu dapat menyebabkan hidrosefalus. Hidrosefalus yang tidak ditangani akan menyebabkan peningkatan TIK dan herniasi otak. Komplikasi lainya adalah kejang, penurunan kesadaran, serta vasospasme. Di luar susunan saraf pusat, SAH juga dapat menyebabkan terjadinya edema paru neurogenik dan neurogenic stunned myocardium. ${ }^{5}$ Jika sudah dilakukan tindakan coiling ataupun clipping aneurisma, risiko paling sering terjadi adalah vasospasme serebral. Patofisiologi vasospasme serebral hingga kini masih belum dapat dimengerti dengan sepenuhnya. Terdapat beberapa teori mengenai penyebab vasospasme serebral, antara lain vasokonstriksi yang memanjang, overproduksi endothelin-1 (ET-1) yang merupakan vasokonstriktor, produksi yang kurang dari Nitric Oxide (NO) yang merupakan vasodilator, "remodelling" akibat inflamasi dan penyempitan dari dinding arteri, dan kombinasi dari faktor-faktor ini. ${ }^{2}$

\section{Gejala Klinis}

Seiring dengan onset yang terlambat, gejala iskemia akibat vasospasme serebral paling sering muncul 1 minggu setelah rupturnya aneurisma, namun dapat terjadi hingga 2 minggu setelah SAH. ${ }^{7}$ Vasospasme serebral simtomatik memiliki onset gradual, ditandai gejala sakit kepala yang bertambah, agitasi, cenderung mengantuk. Gejala dapat memberat jika tidak ditangani. Gejala dari vasospasme serebral simtomatik tergantung pada lokasi otak yang iskemia, jika di lokasi arteri serebri media, maka dapat terjadi monoparesis, hemiparesis atau afasia. Jika vasospasme di arteri cerebri anterior, dapat ditandai gejala kelemahan kaki, kebingungan, mengantuk, sulit bicara. Jika terjadi di arteri vertebrobasiler dapat menyebabkan gejala neurologis yang lebih umum, dengan penurunan kesadaran dan kelemahan tubuh. ${ }^{8}$

Pada pasien dengan kondisi neurologis yang terganggu, vasospasme serebral sulit untuk dideteksi, jadi untuk pasien dengan penurunan kesadaran cara deteksinya berbeda dan penting dilakukan. Gangguan neurologis yang muncul terlambat setelah terjadinya $\mathrm{SAH}$ dapat diakibatkan oleh beberapa hal, seperti meningkatnya edema (di sekitar hematoma intraserebral, kontusio cerebri, atau infark), perdarahan ulang aneurisma atau aneurisma yang tersisa, hidrosefalus, sepsis (akibat meningitis atau ventrikulitis), hiponatremia, hipoksia, dan hipotensi. Adanya satu atau lebih kondisi ini dapat memperburuk defisit neurologis yang sudah ada dan sering dianggap vasospasme serebral. Oleh karena itu, tidak semua perburukan neurologis pasien diakibatkan oleh vasospasme serebral, harus dipikirkan faktor lain. Namun, juga tidak boleh mengabaikan kemungkinan terjadinya vasospasme serebral. Pemeriksaan yang teratur dan teliti merupakan cara terbaik untuk mengenali iskemia awal pada pasien yang sadar. ${ }^{9}$ 
Tabel 2. Modalitas untuk Monitoring dan Deteksi Vasospasme Serebral ${ }^{1,2}$

\begin{tabular}{|c|c|c|}
\hline Modalitas & Keuntungan & Limitasi \\
\hline \multirow{3}{*}{$\begin{array}{l}\text { Evaluasi } \\
\text { neurologis serial }\end{array}$} & Hemat waktu & Subjekif \\
\hline & Tidak invasif & Tidak reliable pada pasien dengan derajat \\
\hline & Biaya minimal & yang buruk \\
\hline \multirow[t]{5}{*}{ TCD } & Tidak invasif & \\
\hline & Spesifik untuk vasospasme MCA & Spesifik untuk vasospasme daerah MCA \\
\hline & & Sensitivitas suboptimal \\
\hline & & Tidak selalu tersedia \\
\hline & & Membutuhkan ahli \\
\hline \multirow[t]{4}{*}{ CTA } & Tidak invasif & $\begin{array}{l}\text { Risiko alergi kontras dan contrast induced } \\
\text { nephropathy }\end{array}$ \\
\hline & Akurasi tinggi & Paparan radiasi \\
\hline & & Overestimasi dari vasospasme \\
\hline & & Tidak selalu tersedia \\
\hline \multirow[t]{2}{*}{ СТP } & Tidak invasif & Paparan radiasi dan kontras \\
\hline & Sensitif dalam diagnosis infark baru & Tidak selalu tersedia \\
\hline \multirow[t]{2}{*}{ MRI } & Tidak invasif & Biaya mahal untuk monitor harian \\
\hline & & Sulit dilakukan untuk pasien kritis \\
\hline \multirow[t]{3}{*}{ MRI Perfusion } & Tidak invasif & Biaya mahal untuk monitor harian \\
\hline & & Tidak selalu tersedia \\
\hline & & Sulit dilakukan untuk pasien kritis \\
\hline \multirow[t]{4}{*}{ Kateter angiografi } & Merupakan gold standard & Invasif \\
\hline & & Risiko paparan radiasi dan kontras \\
\hline & & $\begin{array}{l}\text { Risiko stroke, cidera pembuluh darah, } \\
\text { perdarahan }\end{array}$ \\
\hline & & Butuh pelayanan neuro-intervensi \\
\hline \multirow{4}{*}{$\begin{array}{l}\text { Brain Tissue } \\
\text { Oxygen }(\mathrm{PbtO} 2)\end{array}$} & Dilakukan bedside & Invasif \\
\hline & $\begin{array}{l}\text { Dapat mendeteksi iskemia yang mungkin } \\
\text { tidak ternilai oleh modalitas lain }\end{array}$ & Biaya mahal \\
\hline & $\mathrm{pO}_{2}<10-15 \mathrm{mmHg} \rightarrow$ hipoksia & Tidak selalu tersedia \\
\hline & & $\begin{array}{l}\text { Hanya menggambarkan area tempat probe } \\
\text { terpasang }\end{array}$ \\
\hline \multirow[t]{3}{*}{$\begin{array}{l}\text { Cerebral } \\
\text { microdyalisis } \\
\text { catheter }\end{array}$} & $\begin{array}{l}\text { Dapat mengukur kontinyu hasil } \\
\text { metabolisme sel otak dan menggambarkan } \\
\text { CBF }\end{array}$ & $\begin{array}{l}\text { Hanya menggambarkan hasil metabolisme } \\
\text { parsial }\end{array}$ \\
\hline & Deteksi dini iskemia & Biaya mahal \\
\hline & Dilakukan bedside & Tidak selalu tersedia \\
\hline \multirow[t]{4}{*}{$\begin{array}{l}\text { Near-Infrared } \\
\text { Spectroscopy }\end{array}$} & Dilakukan bedside & $\begin{array}{l}\text { Hanya menggambarkan area tepat probe } \\
\text { terpasang }\end{array}$ \\
\hline & Tidak invasif (probe dipasang di scalp) & $\begin{array}{l}\text { Hanya menggambarkan area tepat probe } \\
\text { terpasang }\end{array}$ \\
\hline & Monitor kontinyu & Sinyal diperngaruhi lapisan scalp \\
\hline & $\begin{array}{l}\text { Pengukuran berdasarkan cahaya yang } \\
\text { diserap oleh Hemoglobin }\end{array}$ & \\
\hline
\end{tabular}




\section{Diagnosis}

Diagnosis vasospasme serebral simtomatik harus menyingkirkan terlebih dahulu penyebab lainnya. Ada beberapa penunjang yang dapat digunakan untuk membantu penegakkan diagnosis vasospasme serebral:2,4

Penurunan patologis dari $C B F$

- Perfusion CT scanning

- Single-photon emission tomography

- Xenon-enhanced CT

- Thermal diffusion flowmetry

Deteksi iskemia atau infark cerebral

- Diffusion-weighted magnetic resonance imaging

- Near-infrared spectroscopy

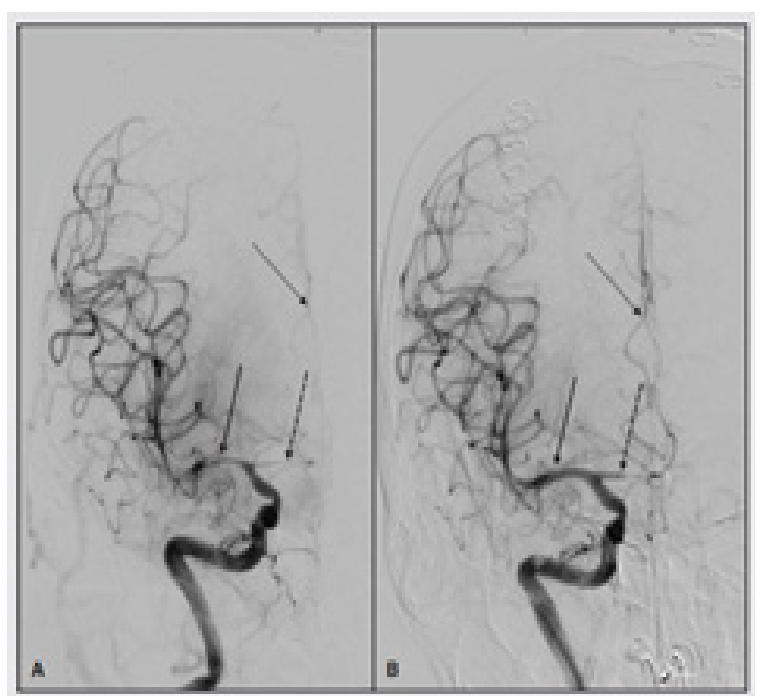

Gambar 1. (A) Gambaran angiografi serebral dari arteri carotis interna, PA cranial view, menunjukkan vasospasme di arteri cerebri media segmen M1 (panah tebal), arteri serebri anterior segmen A1 (panah putus-putus), dan arteri serebri anterior bagian distal (panah titik-titik). (B) Vaskularisasi setelah dilakukan angioplasty untuk menangani vasospasme. ${ }^{1}$

- Microdialysis Direct probe cerebral oximetry

- Jugular venous oxygen saturation

Penciteraan vaskular

- Catheter-based angiography

- CT angiography

\section{Tatalaksana}

Penanganan Umum Perdarahan Subarahnoid

Jika diagnosis SAH sudah ditegakkan, maka perlu secepatnya dilakukan stabilisasi airway, breathing, circulation. Jika GCS rendah dan tidak mampu menjaga patensi jalan napas, maka perlu dilakukan intubasi endotrakeal, namun perlu diingat untuk tidak memicu peningkatan tekanan darah selama manipulasi intubasi. Monitoring jantung penting dilakukan karena seringkali terjadi gangguan neurokardiogenik. ${ }^{1,10-12}$ Penanganan lainnya adalah menurunkan tekanan darah sistolik dan melakukan reverse antikoagulan untuk menurunkan risiko reruptur aneurisma. Tidak ada target tekanan darah yang jelas dan harus mengingat risiko terjadinya iskemia atau infark dengan hipotensi. Guidelines merekomendasikan target TD sistolik $<160 \mathrm{mmHg}$, ada juga yang merekomendasikan 140-150 mmHg. Obat-obatan yang dapat digunakan antara lain nicardipin, labetalol, jika terjadi bradikardia, hydralazine. Nitroprusside dan nitroglycerin harus dihindari karena efek vasodilatasi dan risiko meningkatkan TIK. ${ }^{1,10-12}$

Reversing antikoagulan harus dilakukan secepatnya. Antagonis vitamin K dapat direverse dengan phytonadione (vitamin $\mathrm{K}$ ) dan 4-factor prothrombin complex concentrate (PCC) atau fresh frozen plasma. Jika pasien mendapat antiplatelet, maka dapat diberikan transfusi platelet atau desmopressin. Pemberian transfusi platelet dipertanyakan karena penelitian mengungkapkan peningkatan angka mortalitas pada pasien yang mendapat transfusi platelet pada pasien yang menkonsumsi antiplatelet pada kasus perdarahan intracerebral spontan. Akan tetapi, penelitian ini hanya pada pasien dengan perdarahan intracerebral, bukan SAH yang secara patofisiologi berbeda. Pada pasien yang mengkonsumsi direct thrombin inhibitor seperti dabigatran dapat direverse dengan idarucizimab. Jika pasien mendapat faktor $\mathrm{Xa}$ inhibitor, termasuk unfractioned heparin atau fondaparinux, dapat diberikan PCC sebagai lini pertama atau adexanet alpha. ${ }^{1,10-12}$ Pencegahan risiko ruptur ulang aneurisma dengan mengatasi nyeri, mual muntah, valsava 
dengan pemberian analgesia, antiemetik dan laksatif. Nimodipine, yang merupakan calcium channel blocker diberikan untuk memperbaiki luaran pasien SAH dapat diberikan sesegera mungkin dengan tetap memperhatikan risiko turunnya tekanan darah. Obat antikejang dapat diberikan jika kondisi neurologis buruk, jumlah SAH banyak, dan terdapat risiko kejang. Obat yang dapat diberikan adalah fenitoin, fosfenitoin, levetiracetam. Penanganan lainnya adalah menjaga kondisi euvolemiadan elevasi kepala 30 derajat untuk mencegah aspirasi dan perbaikan drainase jugular. ${ }^{110-12}$ Tindakan definitif dapat dilakukan terapi definitif dengan clipping atau coiling ataupun beberapa pasien membutuhkan drainase ventrikulostomi, untuk hidrosefalus atau menurunkan TIK selama prosedur. Semakin awal prosedur dilakukan maka risiko terjadinya perdarahan ulang berkurang. ${ }^{1,10-12}$

\section{Berdasarkan International Cooperative} Study on the Timing of Aneurysm Surgery, direkomendasikan pasien dengan SAH yang menjalani operasi pada hari ke 4-10 pasca perdarahan akan mengalami luaran yang lebih buruk dibandingan pasien yang ditangai di hari 0-3 dan hari 11-14. Pasien dengan SAH pada hari ke 4-10 harus dilakukan penundaan operasi aneurisma sampai hari ke-10. Namun dengan semakin banyaknya penelitian dilakukan, saat ini direkomendasikan untuk melakukan secepatnya tindakan clipping ataupun coiling aneurisma. Ditemukan bahwa kondisi klinis pasien saat datang ke rumah sakit merupakan faktor penting yang mempengaruhi luaran. Operasi yang dilakukan awal lebih superior dibandingkan jika ditunda. Luaran yang buruk dan kematian akan lebih rendah pada pasien yang kondisi klinisnya baik, dan pada pasien yang datang dengan kondisi klinis yang buruk, tindakan yang lebih awal akan menurunkan luaran yang buruk pada pasien. Jika aneurisma sudah diatasi dengan coiling atau clipping maka risiko selanjutnya adalah vasospasme serebral dan DCI. ${ }^{11}$

\section{Penanganan Vasospasme dan Iskemia Cerebri} Meningkatkan $\mathrm{CBF}$ melalui kolateral sekitar pembuluh darah dengan meningkatkan volume dan tekanan darah sistemik dapat membalikkan iskemia cerebral, dan terapi farmakologis atau dilatasi balon pada arteri yang menyempit dapat "membalikkan" vasospasme serebral.,,9

\section{Induced Hypertension}

Terapi Triple- $H$ yakni hipervolemia, hipertensi, hemodilusi merupakan kombinasi yang bertujuan memperbaiki cardiac output, meningkatkan CPP dan mengoptimalisasi transportasi oksigen. Derajat hemodilusi yang diberikan dengan ekspansi volume dan mengurangi viskositas darah dapat memperbaiki penghantaran oksigen dengan menjaga hematokrit lebih dari 30 (hemoglobin dijaga lebih dari $9 \mathrm{~g} / \mathrm{dL}$ ). Jika vasospasme serebral didiagnosis atau diduga kuat terjadi, terapi dimulai dengan ekspansi volume dengan infus kristaloid (dengan mengingat kondisi jantung pasien). Tidak ada keuntungan lebih dari volume ekspansi jika melebihi CVP 8-10 mmHg., ${ }^{2,10}$ Akan tetapi praktis hipervolemia dan hemodilusi semakin ditinggalkan, karena hemodilusi hipervolemia ataupun isovolemia tidak menunjukkan bukti ilmiah yang bermakna. Induced hypertension saja atau dikombinasi dengan hipervolemia menunjukkan tetap menghasilkan perbaikan $\mathrm{CBF}$ yang memperbaiki luaran pasien dengan SAH. Peningkatan CBF dengan hemodilusi hipervolemia hanya berlangsung sementara dan tidak cukup untuk mencegah iskemia dan infark. Penghantaran oksigen tidak meningkat meskipun terjadi peningkatan CBF. Yang terpenting adalah dengan meningkatkan tekanan darah yang dapat meningkatkan $\mathrm{CBF}$ atau dikenal dengan induced hypertension. ${ }^{2,10}$ Vasospasme simtomatik dapat diterapi dengan pemberian vasopresor, yakni phenylephrine (dosis titrasi maksimum 180 $\mu \mathrm{g} / \mathrm{kg} / \mathrm{menit}$ ) atau norepinephrine (dosis titrasi maksimum $20 \mu \mathrm{g} / \mathrm{kg} / \mathrm{menit}$ ). Tujuan pemberian vasopresor adalah meningkatkan tekanan darah dengan segera. Terkadang dibutuhkan tekanan darah sistolik lebih dari $200 \mathrm{mmHg}$ atau CPP lebih dari $80 \mathrm{mmHg}$, namun jika tanda iskemia terjadi pada tekanan darah kisaran ini atau lebih tinggi, maka terapi ini dianggap gagal. Peningkatan tekanan darah yang ekstrim ini dapat memperberat iskemia otak dan edema cerebri menyebabkan peningkatan TIK. Harus diingat bahwa hipertensi dan hipervolemia tidak meningkatkan risiko perdarahan dari aneurisma 
yang belum ruptur, pada kondisi yang akut. Risiko dari terapi Triple-H adalah gagal jantung dan infark jantung, edema paru, dan komplikasi yang berhubungan dengan pemasangan CVC. Risiko meningkat pada pasien usia tua dan yang memiliki riwayat penyakit kardiopulmoner. ${ }^{2}$

\section{Endovascular Reversal of Vasospasm}

Jika tujuan perbaikan hemodinamik dengan Triple- $H$ tidak tercapai pada pasien dengan gejala iskemia serebral yang persisten, atau jika pasien memiliki status kardiopulmoner yang tidak baik, maka dapat dilakukan terapi endovaskular. Pemeriksaan CT kepala harus dilakukan terlebih dahulu untuk menyingkirkan adanya infark cerebri. Pada kondisi vasospasme serebral simtomatis, angiografi dapat menunjukkan segmen vaskular mana yang terkena, namun harus dikorelasikan dengan klinis dan hasil TCD. Balloon angioplasty ini paling baik dilakukan dalam waktu 2 jam pertama setelah onset. Komplikasi yang mungkin terjadi adalah ruptur pembuluh darah dan lepasnya coil atau clip aneurisma. ${ }^{2,10}$ Jika lokasi tidak memungkinkan, operator biasa akan memberikan intra-arterial lokal vasodilator. Milrinone, yang merupakan penghambat phosphodiesterase III selektif, dapat diberikan melalui mikrokateter proksimal terhadap pembuluh darah yang vasospastik. Namun harus diperhatikan keungkinan terjadinya instabilitas hemodinamik, karena itu infus milrinone diberikan secara kontinyu selama 30-40 menit. Vasodilator intra-arterial lain, seperti papaverine, nifedipine, verapamil, dan nimodipine dapat digunakan untuk vasospasme serebral, namun hasil penelitiannya tidak signifikan. ${ }^{2,10}$

\section{Pencegahan Vasospasme Serebral dan Proteksi Otak}

\section{Strategi Pencegahan Umum}

Pasien cenderung memiliki volume yang inadekwat saat periode akut SAH dan hipovolemia harus dihindari. Tidak ada studi yang menunjukkan induce hipervolemia dengan melakukan terapi volume memberikan keuntungan dalam mencegah vasospasme atau iskemia meskipun pada pasien dengan fungsi ginjal yang normal. Pasien SAH dapat mengalami natriuresis yang berlebihan yang dikenal sebagai "cerebral salt wasting", yang berhubungan dengan peningkatan brain natriuretic peptide, dan rentan mengalami hiponatremia dalam kondisi ini. Hiponatremia meningkatkan risiko vasospasme dan berhubungan dengan derajat infark yang lebih buruk. Hiponatremia pada pasien SAH tidak ditangani dengan restriksi cairan, namun dengan penggantian natrium dengan pemberian saline $0.9 \%$ atau $3 \%$, dikombinasi dengan fludrocortisone jika mengalami vasospasme. ${ }^{2}$ Pasien harus cukup hidrasi dengan kristaloid isotonik, TIK dijaga normal dengan penggunaan EVD, dan CPP dipertahankan di atas $70 \mathrm{mmHg}$. Pemeriksaan TCD harian dapat dilakukan untuk menilai perkembangan ke vasospasme serebral, jika nilainya melebihi $200 \mathrm{~cm} /$ detik pada MCA maka merupakan indikasi terjadinya vasospasme serebral pada pembuluh darah tersebut. Evaluasi klinis secara regular terhadap status kesadaran, verbal, dan pergerakan tangan penting dilakukan. Pasien yang mengalami penurunan kesadaran atau tersedasi karena penggunaan ventilator, harus dilakukan pemeriksaan penciteraan vaskular (CT angiografi) pada SAH hari ke-5 dan beberapa hari kemudian jia diperlukan. ${ }^{2,9}$

Anemia merupakan penanda yang berperan terhadap morbiditas pada pasien SAH. Transfusi darah berhubungan dengan risiko lebih tinggi terjadinya vasospasme dan morbiditas. Kadar hemoglobin optimal pada pasien dengan SAH dianggap adekwat jika lebih dari $9 \mathrm{~g} / \mathrm{dL} .{ }^{2,10}$ Nimodipine $60 \mathrm{mg}$ setiap 4 jam, dapat diberikan melalui per oral atau nasogastric tube (NGT) diberikan hingga 3 minggu, merupakan terapi standar pada pasien dengan SAH akibat aneurisma. Nimodipine mencegah peningkatan kalsium intracellular dengan menghambat dihydropyridine-sensitive (L-type) calcium channels. Namun mekanisme kerjanya pada pasien dengan SAH masih belum diketahui. Dianggap nimodipine sebagai agen neuroprotektif. Nimodipine dapat menyebabkan penurunan sementara tekanan darah. Jika perlu, dosis dapat diturunkan namun diberikan lebih sering, misalnya $30 \mathrm{mg}$ setiap 2 jam..$^{7,13}$ Pemberian fenitoin dihindari kecuali jika pasien 
mengalami kejang, pemberian kortikosteroid tidak disarankan. Ventilasi dan oksigenasi yang optimal, pencegahan demam, menjaga euglikemia, nutrisi yang baik dan kadar elektrolit yang normal penting untuk mengurangi efek dari vasospasme dan iskemia yang terlambat. , $, 7,10^{2}$

\section{Profilaksis Balloon Angioplasty}

Meskipun terdapat trend yang menunjukkan berkurangnya vasospasme serebral pada pasien yang ditangani dengan percutaneous transluminal balloon angioplasty, namun luaran tidak berbeda dengan kontrol dan keamanan prosedur ini masih dipertanyakan karena risiko ruptur pembuluh darah. ${ }^{11,13}$

\section{Pembersihan Bekuan Darah}

Trombolisis intracisternal dengan recombinant tissue plasminogen activator atau urokinase mempercepat pembersihan dari bekuan darah subarahnoid dan menunjukkan prosedur ini dapat mencegah vasospasme serebral. Namun, pertimbangkan keamanan memasukkan agen trombolisis ke rongga subarahnoid yang sedang mengalami "cedera". 2

\section{Vasodilator Intratekal}

Implan Nicardipine lepas lambat yang diletakkan di rongga subarahnoid pada pasien dengan bekuan darah yang tebal dan menjalani clipping, secara signifikan menunjukkan dapat mencegah vasospasme serebral dan iskemia. Namun, hal ini belum diteliti lebih lanjut. ${ }^{2}$

\section{Magnesium}

Magnesium sulfate (MgSO4) memiliki properti neuroprotektif dan vasodilator, sehingga diuji untuk pencegahan vasospasme serebral dan iskemia pada pasien dengan SAH. Studi Intravenous Magnesium Sulfate for Aneurysmal Subarachnoid Hemorrhage (IMASH; 327 pasien) dan IMASH-2 (1204 pasien), menunjukkan intravenous magnesium (20 mmol $\mathrm{MgSO} 4$ diberikan selama 30 menit diikuti dengan infus kontinyu 80 mmol MgSO4 setiap hari selama 14 hari), tidak menunjukkan kemungkinan perbaikan luaran atau penurunan risiko infark cerebri, vasospasme angiografi atau mortalitas. Tidak ada bukti yang menunjukkan pemberian $\mathrm{MgSO} 4$ bermanfaat untuk pencegahan vasospasme serebral pasca SAH. ${ }^{12,14}$

\section{Endothelin Receptor Antagonist}

Produksi Endothelin-1 (ET-1) yang berlebihan dari kerusakan sel endothelial otak akibat SAH merupakan teori yang mendasari pathogenesis vasospasme serebral. Antagonis reseptor ETA/B, TAK-044, ditemukan dapat mengurangi iskemia yang terlambat, memiliki profil keamanan yang baik, namun tidak ada pengaruh pada luaran pasien. Antagonis reseptor ETA, clazosentan, memiliki hasil yang menjanjikan pada studi Clazosenatan to Overcome Neurological iSChemia and Infarct OccUrring after Subarachnoid hemorrhage [CONSCIOUS-1,2,3], akan tetapi masih belum diketahui mengapa clazosentan mengurangi penyempitan arteri yang vasospastik, namun tidak mengurangi kejadian dari luaran yang buruk. ${ }^{2,10}$

\section{Statin}

Agen statin menghambat 3-hydroxyl-3methylglutaryl coenzyme A reductase, yang merupakan rate-limiting enzyme pada jalur mevalonate dari sintesis kolesterol. Statin selain memiliki aktivitas hipolipidemik juga memiliki kemampuan memperbaiki fungsi endotelial, memodulasi respons inflamasi, menjaga stabilitas dari plak aterosklerosis, dan mencegah terbentuknya trombus. Statin juga memperbaiki CBF dengan meningkatkan regulasi dari eNOS. Statin meningkatkan biosintesis dan bioavailabilitas dari NO sehingga dapat menjadi profilaksis terjadinya vasospasme serebral pada SAH. ${ }^{2}$

\section{Simpulan}

Vasospasme serebral masih menjadi masalah utama pada pasien dengan perdarahan subarahnoid. Onset vasospasme serebral yang bervariasi, mulai dari 24 jam pasca SAH sampai dengan 14 hari, dengan puncak kejadian pada hari ke-7, patofisiologi vasospasme serebral yang kompleks dan belum adanya terapi yang pasti, turut berkontribusi terhadap morbiditas dan mortalitas yang tinggi pada pasien dengan $\mathrm{SAH}$. Deteksi awal terjadinya iskemia dan penanganan secepatnya harus segera dilakukan. 
Evaluasi neurologis scara teliti dan berkala, dibantu dengan monitor untuk deteksi iskemia cerebral, dapat membantu mendeteksi terjadinya vasospasme serebral sedini mungkin. Terapi pencegahan dengan terapi manajemen cairan yang cukup, induced hypertension dan Nimodipine, serta menghindari terjadinya cidera otak sekunder sangat penting. Jika terapi umum gagal, dapat dipertimbangkan dilakukan terapi endovaskular berupa balloon angioplasty jika fasilitas memungkinkan.

\section{Daftar Pustaka}

1. Shehabeldin M, Alderazi Y. Management of cerebral vasospasm following aneurysmal subarachnoid hemorrhage. Southwest Respir Crit Care Chronicles. 2017;5(20):33-43.

2. Findlay JM, Nisar J, Darsaut T. Cerebral vasospasm: a review. Can J Neurol Sci. 2016;43(1):15-32.

3. van Lieshout JH, Dibué-Adjei M, Cornelius JF, Slotty PJ, Schneider T, Restin T, dkk. An introduction to the pathophysiology of aneurysmal subarachnoid hemorrhage. Neurosurg Rev. 2018;41(4):917-30.

4. Frontera JA, Fernandez A, Schmidt JM, Claassen J, Wartenberg KE, Badjatia N, dkk. Defining vasospasm after subarachnoid hemorrhage: what is the most clinically relevant definition? stroke. 2009;40(6):19638.

5. Ciurea A V., Palade C, Voinescu D, Nica DA. Subarachnoid hemorrhage and cerebral vasospasm - literature review. J Med Life. 2013;6(2):120-5.

6. Inagawa $\mathrm{T}$, Yahara $\mathrm{K}$, Ohbayashi N. Risk factors associated with cerebral vasospasm following aneurysmal subarachnoid hemorrhage. Neurol Med Chir (Tokyo). 2014;oa-2013.

7. Nassar HGE, Ghali AA, Bahnasy WS, Elawady MM. Vasospasm following aneurysmal subarachnoid hemorrhage: prediction, detection, and intervention. Egypt J Neurol psychiatry Neurosurg. 2019;55(1):1-6.

8. LiuY, Qiu H-C, Su J, Jiang W-J. Drug treatment of cerebral vasospasm after subarachnoid hemorrhage following aneurysms. Chinese Neurosurg J. 2016;2(1):1-8.

9. Chugh C, Agarwal H. Cerebral vasospasm and delayed cerebral ischemia: review of literature and the management approach. Neurol India. 2019;67(1):185.

10. Roberts D, Nourollah-Zadeh E. Cerebral vasospasm after subarachnoid hemorrhage: is more endovascular therapy the answer? Neurology. AAN Enterprises; 2019. 93:1923.

11. Bauer AM, Rasmussen PA. Treatment of intracranial vasospasm following subarachnoid hemorrhage. Front Neurol. 2014;5:72.

12. Li K, Barras CD, Chandra R V, Kok HK, Maingard JT, Carter NS, et al. A review of the management of cerebral vasospasm after aneurysmal subarachnoid hemorrhage. World Neurosurg. 2019;126:513-27.

13. Zwienenberg-Lee M, Hartman J, Rudisill N, Madden LK, Smith K, Eskridge J, et al. Effect of prophylactic transluminal balloon angioplasty on cerebral vasospasm and outcome in patients with fisher grade III subarachnoid hemorrhage: results of a phase II multicenter, randomized, clinical trial. Stroke. 2008;39(6):1759-65.

14. Mees SMD, Algra A, Vandertop WP, van Kooten F, Kuijsten HAJM, Boiten $\mathrm{J}$, et al. Magnesium for aneurysmal subarachnoid haemorrhage (MASH-2): a randomised placebo-controlled trial. Lancet. 2012;380(9836):44-9. 